\title{
Relationship between the Phylogenetic Group of Escherichia coli Strains Isolated in Water and Fish in Fresco Lagoon (Côte d'Ivoire)
}

\author{
Nadège Kouadio-Ngbesso ${ }^{1,2 *}$, Nazaire Kouassi ${ }^{3}$, Kouadio Florent N'guessan ${ }^{2}$, \\ Ama Adingra ${ }^{1}$, Bassa Antoine Yobouet ${ }^{2}$, Adjéhi Dadié ${ }^{2}$ and Koffi Marcellin Djè \\ ${ }^{1}$ Centre de Recherches Océanologiques, BP V 18 Abidjan, Côte d'Ivoire \\ ${ }^{2}$ Laboratoire de Biotechnologie et Microbiologie des Aliments, UFR-STA, Université Nangui \\ Abrogoua, 02 BP 801 Abidjan 02, Côte d'Ivoire \\ ${ }^{3}$ Centre National de Recherches Agronomiques, 01 BP 1740 Abidjan 01, Côte d'Ivoire \\ *Corresponding author
}

\begin{tabular}{|c|c|}
\hline & A B S T R A C T \\
\hline Keywor & \multirow{4}{*}{$\begin{array}{l}\text { The aim of this study was to know the quality of water and some of the fish from } \\
\text { Fresco lagoon, a RAMSAR site. In total, } 376 \text { samples including } 216 \text { water samples } \\
\text { and } 160 \text { fish (viscera and gills) were collected in six sites and lagoon respectively. } \\
\text { They analysed by the standard microbiological test for Escherichia coli isolation. } \\
\text { Identification and phylogenetic affiliation of E. coli were performed by PCR. In } \\
\text { water, } 338 \text { strains of E. coli were isolated. From fish, } 86(53.75 \%) \text { E. coli were } \\
\text { isolated from the viscera and } 74(46.25 \%) \text { from the gills. In water and fish, the } \\
\text { phylogenetic group A was the most frequent ( } 69.82 \% \text { and } 81.25 \% \text {, respectively), } \\
\text { followed by the group B1 ( } 23.67 \% \text { and } 13.75 \% \text {, respectively). The group B } 2 \text { was } \\
\text { rare in water ( } 4.44 \%) \text { and fish ( } 5 \%) \text { while D ( } 2.07 \% \text { in water) was absent in fish. } \\
\text { Strains of groups B2 and D are usually more pathogenic than A and B1 and they } \\
\text { are frequently responsible for extra-intestinal infections. Our findings indicate that } \\
\text { Fresco lagoon could represent a potential reservoir of extra-intestinal infections for } \\
\text { the riverine populations and consumers. }\end{array}$} \\
\hline $\begin{array}{l}\text { Escherichia coli, } \\
\text { fish, } \\
\text { Fresco lagoon } \\
\text { water, } \\
\text { phylogenetic }\end{array}$ & \\
\hline & \\
\hline & \\
\hline
\end{tabular}

\section{Introduction}

Fresco lagoon, like many African coastal lagoons, is under consistent and sometimes severe pressure from diverse forms of human activities emanating from the surrounding city and villages. The indiscriminate dumping of untreated wastes into this aquatic environment could bring about physical, chemical and biological deteriorations of the water body. This will no doubt endanger the resident aquatic organisms as well as impair the beneficial uses of the water. However, a paucity of information exists on the extent of biological pollution of the Fresco lagoon and hence its public health implication. In a recent study, we isolated fourteen biotypes of $E$. coli from fishes and water samples from Fresco lagoon (Kouadio et al., 2011).

Escherichia coli is a normal inhabitant of the lower intestinal tract of warm-blooded 
animals and humans. However, in recent years, this species was found in some coldblooded animals such as fish (Hansen et al., 2008; Yagoub, 2009; Soliman et al., 2010; Sujatha et al., 2011). Phylogenetic studies show that there are four main phylogenetic groups of $E$. coli, designated A, B1, B2, and D (Herzer et al., 1990; Clermont et al., 2000). According to Lecointre et al., (1998), groups A and B1 are sister groups whereas group B2 is included in an ancestral branch. These phylo-groups apparently differ in some characteristics, such as their ability to use different sugar sources, their antibioticresistance profiles and their growth rate. Walk et al., (2007) demonstrated that the majority of the E. coli strains that are able to persist in the environment belong to group B1. E. coli strains are usually referred to as commensal, intestinal or extra-intestinal pathogenic (Russo and Johnson, 2000). Extra-intestinal pathogenic strains belong to groups B2 and D (Picard et al., 1999; Johnson and Stell, 2000), commensal strains to groups A and B1 (Johnson et al., 2001). The pathogenic strains have been associated with several diseases including diarrhea, urinary tract infections and meningitis (Russo and Johnson, 2003; Unno et al., 2009).

The aim of this study was to know the quality of water and some of the fish from Fresco lagoon, a RAMSAR site.

\section{Materials and Methods}

\section{Water and fish sampling}

A total of 216 water samples were collected from Fresco lagoon. The sampling sites (figure 1) were purposely selected from Fresco city and its surrounding areas based on the direct influence of sewage and two rivers Niouniourou and Bolo. Water samples $(250 \mathrm{ml})$ were collected at each site, $20 \mathrm{~cm}$ below the surface of the lagoon using sterile glass bottles, stored on ice and transported to the laboratory. All the samples were collected monthly from January 2008 to June 2009. Moreover, 160 fish samples (Tylochromis jentenki, Sardinella maderensis, Sarotherodon melanotheron and Chrysichthys nigrodigitatus) were harvested in the lagoon during the same period. Immediately after collection, samples were chilled in an ice cooler box at $4{ }^{\circ} \mathrm{C}$ and transported to the laboratory of the Oceanology Research Centre (CRO) for analysis within $24 \mathrm{~h}$ after sampling.

\section{E. coli strains isolation and identification}

A volume of $100 \mathrm{ml}$ of water were filtered using membrane filter technique (U.S. EPA; 2002) and placed directly on EMB agar medium (Merck, France). For fish samples, the skin was washed with $70 \%$ ethanol before taking the gills and viscera. Both, 10 $\mathrm{g}$ of gills and viscera were taken aseptically and were suspended each one in $90 \mathrm{ml}$ in sterile peptone water solution in glass bottles and incubated at $37^{\circ} \mathrm{C}$ during 24 hours. Aliquots of $0.1 \mathrm{ml}$ of the suspension were inoculated onto EMB agar medium. The culture plates were then incubated at $37{ }^{\circ} \mathrm{C}$ for $24 \mathrm{~h}$.

Five typical colonies of $E$. coli purple with metallic sheen per plate, were purified by inoculating onto two duplicates of Plate Count Agar (PCA, Merck, Germany), subsequent growth for $18-24$ hours at $37^{\circ} \mathrm{C}$ and subjected to cytochrome oxidase and catalase production. Biochemical identification was done using the API $20 \mathrm{E}$ kit (Biomerieux SA, France) according to the manufacturer's instruction.

Stock cultures were stored in Brain Heart Infusion broth (BHI) (Difco, Michigan, USA) with $20 \%$ glycerin at $-80^{\circ} \mathrm{C}$ until use. 


\section{Extraction of bacterial DNA}

Genomic DNA of typical E. coli isolates were grown in Luria-Bertani (LB) broth at $37{ }^{\circ} \mathrm{C}$ overnight. Bacteria from $1.5 \mathrm{ml}$ of growth medium were pelleted by centrifugation at $1200 \mathrm{~g}$ for $10 \mathrm{~min}$. The bacterial pellet was suspended in $200 \mu \mathrm{l}$ of sterile ultrapure water and was boiled at 100 ${ }^{\circ} \mathrm{C}$ for $10 \mathrm{~min}$. The mixture was centrifuged again at $1200 \mathrm{~g}$ for $10 \mathrm{~min}$. The supernatant containing the DNA was stored at $-20^{\circ} \mathrm{C}$ and used as template in the PCR assays.

\section{Phylogenetic group determination}

The phylogenetic group of each isolated strain was determined by the triplex PCR as previously reported by Clermont (Clermont et al., 2000). The amplified genes were chuA, yjaA genes and DNA fragment TSPE4.C2. Amplification was performed in a PCR thermocycler Biometra Uno II, (Biotron 1998, Germany) according to Clermont et al., (2000) program.

The PCR products were analyzed in $1.8 \%$ agarose gel prepared in $0.5 \mathrm{X}$ TBE buffer (Tris Borate EDTA, Fermentas) containing ethidium bromide $(0.2 \mu \mathrm{g} / \mathrm{ml})$. Electrophoresis was carried out at 100 volts for $40 \mathrm{~min}$. Finally, the gel was photographed using UV light (Uvitec camera, United Kingdom). A 1 kb DNA molecular size marker (BioLabs, France) was included in all gels to allow standardization and sizing.

Phylogenetic groups were determined using the dichotomous tree described by Clermont (Clermont et al., 2000).

\section{Statistical Analysis}

The software ADE4 was used to study the link between phylogenetic groups or subgroups and their host. A Factorial Correspondence Analysis (AFC) was performed using the phylogenetic groups and subgroups distribution. Sites and fish classification were based on these distributions.

\section{Results and Discussion}

\section{Isolation rates of $\boldsymbol{E}$. coli in fish samples}

One hundred and sixty (160) strains of $E$. coli were isolated from fish samples. The identification of $E$. coli isolated in different fish species indicated that Sarotherodon (72.5\%) seemed to be more contaminated than other fish species followed by Tylochromis (47.5\%), Sardinella (45\%) and Chrysichthys (35\%). The distribution of $E$. coli within different parts of fish collected from the lagoon showed that viscera was most contaminated $(53.75 \%)$ than gills (46.25\%). Tylochromis and Sarotherodon showed high percentage of $E$. coli isolates from gills $52.63 \%$ and $68.97 \%$ respectively. However, Sardinella and Chrysichthys showed high percentage in the viscera $83.33 \%$ and $71.43 \%$ respectively (Figure 2 ).

\section{Phylogenetic group of strains isolated from water and fishes}

Dichotomous decision tree to determine the phylogenetic group of $E$. coli strain revealed the presence of groups A, B1, B2 and D in water strains. Of 338 strains of E. coli isolated from Fresco lagoon water, strains of group A were the most frequent $(69.82 \%)$, followed by strains of group B1 (23.67\%). Strains of groups B2 and D were rare (4.44\% and $2.07 \%$ respectively) (Table 1 ). As opposed to groups B2 and D, strains of groups $\mathrm{A}$ and $\mathrm{B} 1$ were isolated at all the sampling sites. The highest percentages of strains from group A were found at sites 1 and $6(17.75 \%$ and $17.16 \%$ respectively). 
Our results also showed that only site 4 exhibited the four phylogenetic groups. Sites 1, 3 and 6 on one hand and the sites 2 and 5 on the other hand have the same phylogenetic profiles.

Of the 160 strains recovered from fish species, only three phylogenetic groups A, $\mathrm{B} 1$ and $\mathrm{B} 2$ divided in 4 subgroups $\mathrm{A} 0, \mathrm{~A} 1$, $\mathrm{B} 1$ and B23 were found (Tables 2). A0 and A1 are including in group A, subgroup B1 in group B1 and subgroup B23 in group B2. The majority of strains isolated were from group A $(81.25 \%)$. The groups B1 and B2 respectively totalized $13.75 \%$ and $5 \%$ of all analyzed strains. Phylogenetic distribution of $E$. coli strains according to the four fish species studied showed that the phylogenetic group A is present in all species. Sarotherodon and Sardinella are the only species to have the groups A, B1 and B2 in viscera (figure 3 ). The phylogenetic group B1 is identified in all species except Chrysichthys while B2 is present only in viscera of Sarotherodon and Sardinella.

\section{Relationship between phylogenetics groups and their host}

To study the link between phylogenetic groups or subgroups and their host, a Factorial Correspondence Analysis (AFC) was performed using their (the phylogenetic groups and subgroups) distribution (Tables 1 and 2). The bidimensional representation of phylogenetics group distribution in each site is shown in Figure 4. This representation can explain $95.08 \%$ of the total inertia. The horizontal axis represents $58.99 \%$ of the total inertia. According to this analysis, the group distribution revealed that sites $1,2,3$ and 6 were similar and influenced by $E$. coli phylogenetic groups A, B1 and B2. Site 4 was particularly influenced by $E$. coli phylogenetic group D. Site 5 is under the influence by $E$. coli phylogenetic group B1.
Sites 1, 2, 3 and 6 are linked and represented one group and sites 4 and 5 the second ones.

Correspondence analysis between fish according to phylogenetic subgroup revealed that Sarotherodon melanotheron and Sardinella maderensis were influenced by $E$. coli phylogenetic subgroups B1 and B23. Tylochromis jentenki and Chrysichthys nigrodigitatus are under the influence of strains belonging to the subgroup A1 (Figure $5)$. The similarity among fishes revealed that fishes were split up in three (height 0.2), Chrysichthys group, Tylochromis group and Sardinella with Sarotherodon in the same group.

Escherichia coli is the most important microbiological parameters taken into account in controlling the quality of bathing waters and its presence is enough to confirm that it is indeed a pollution from fecal contamination (Joly and Reynaud, 2003). For surface water used as a primary contact recreation, the fecal coliform counts shall not exceed $100 \mathrm{CFU} / 100 \mathrm{ml}$ of water analyzed (WHO, 1998). The survey of the $E$. coli along the Fresco lagoon revealed that this lagoon is not polluted as the bacterial counts were below these guidelines for minimizing the health risks associated with water contact activities. However, the pollution can increase over the years due to the population behaviors. As the population of Fresco grows the waste generation also increases. Many illegal sewers, especially from markets and septic tank effluent will continue to directly enter into the lagoon and increase the pollution.

Bacteria form a link between primary producers and consumers; it would therefore appear that pollution affects the aquatic food chain. The use of E. coli as a sanitary indicator for fish samples has been first reported in the 1930s (Costa, 2013). Fecal 
coliforms in fish are influenced by fish feeding habits and fish can harbor fecal coliforms up to 14 days after being exposed to contaminated water (Hansen et al., 2008). The analyses of $E$. coli presence in different fish species indicated that Sarotherodon seemed to be more contaminated, followed by Tylochromis, Sardinella and Chrysichthys. Sarotherodon, Chrysichthys and Tylochromis are bottom feeder while Sardinella is filter feeder. The presence of $E$. coli in our bottom feeder could be explained by the fact that these fishes live and feed in the mud (sediment) where the presence of $E$. coli is generally more abundant than in water (Desmarais et al., 2002; Ishii et al., 2007). Sediment materials probably provide to bacteria some protection against light-induced inactivation.

Considering these facts, it appears less likely that pelagic fish (Sardinella) will ingest or be inoculated by as many $E$. coli as benthic fish (Hansen et al., 2008). Analyses of the fish gills and viscera showed that the rate of E. coli in Sardinella and Chrysichthys is higher in viscera than in gills. These results agreed with those of Lee and Marks (2009) who indicated that $E$. coli is a bacterium that commonly lives in the intestines of people, animals and fish. Hansen et al., (2008) also reported that $E$. coli was firstly discovered in intestine of wild fish. Fish may also absorb bacteria from its feeding and surrounding water, these bacteria accumulate in various organs in significant proportions.

Since contamination from $E$. coli represents a risk for human health, we decided to gather more information about $E$. coli strains isolated from water and fish samples by assigning them to the phylogenetic groups $\mathrm{A}, \mathrm{B} 1, \mathrm{~B} 2$ and $\mathrm{D}$ using the PCR based technique described by Clermont et al. (2000). As expected, the four phylogenetic groups were found within water isolates strains. Strains belonging to groups $\mathrm{A}$ and $\mathrm{B} 1$ are the majority with more than $75 \%$ strains distributed across all sites. Duriez et al., (2001) found that in 168 nonepidemiological related isolates from three geographically distinct human populations, strains from phylogenetic groups A and B1 were the most common; strains of the group B2 were rare. E. coli strains are usually referred to as commensal, intestinal or extraintestinal pathogenic (Russo and Johnson, 2000). Extraintestinal pathogenic strains belong to groups B2 and D (Johnson and Stell, 2000; Clermont et al., 2000), the commensal strains to groups A and B1 (Johnson et al., 2001). Our study demonstrated that the commensal are the most abundant strains in the water of Fresco lagoon. This may confirm the fact that the lagoon is the receptacle of humans and animals' feces. E. coli isolated from lagoon water showed the 4 phylogenetic groups not only among isolates from different sites but also among those of the same site. The relationships between site according to the distribution of phylogenetic groups revealed that sites were classed in 2 groups. The group composed by sites 4 and 5 could be under same multiple sources of fecal contamination. They received river inputs (Niouniourou and Bolo), wastewaters, sediment, and uncontrolled urban discharges.

E. coli isolated from fish showed 3 phylogenetic groups A, B1 and B2 not only among isolates from different fish species but also among those of the same fish species. Strains belonging to groups D were not found in fish. The relationships between fishes according to the distribution of phylogenetic groups revealed that fishes were classed in 3 groups where Sardinella and Sarotherodon constituted the same group. 
Table.1 Distribution of E. coli strains from water of Fresco lagoon among the four phylogenetic groups according to sites (\%)

\begin{tabular}{|c|c|c|c|c|c|c|c|}
\hline \multirow{2}{*}{$\begin{array}{l}\text { Phylogenetic } \\
\text { groups }\end{array}$} & \multicolumn{6}{|c|}{ Sites } & \multirow[t]{2}{*}{ Total } \\
\hline & Site 1 & Site 2 & Site 3 & Site 4 & Site 5 & Site 6 & \\
\hline $\mathrm{A}$ & 17.75 & 9.76 & 7.40 & 9.17 & 8.58 & 17.16 & 69.82 \\
\hline B1 & 4.73 & 5.03 & 1.18 & 1.78 & 4.73 & 6.21 & 23.67 \\
\hline B2 & 1.18 . & 00 & 1.18 & 0.59 & 00 & 1.48 & 4.44 \\
\hline $\mathrm{D}$ & 00 & 0.89 & 00 & 0.59 & 0.59 & 00 & 2.07 \\
\hline
\end{tabular}

Table.2 Distribution of the E. coli phylogenetic subgroups among fish analyzed

\begin{tabular}{|c|c|c|c|c|c|}
\hline \multirow{2}{*}{$\begin{array}{l}\text { Subgroups } \\
\text { phylogenetic }\end{array}$} & \multicolumn{4}{|c|}{ Fish species } & \multirow[b]{2}{*}{ Total } \\
\hline & Tylochromis & Chrysichthys & Sarotherodon & Sardinella & \\
\hline A1 & 34 & 28 & 39 & 22 & 123 \\
\hline A0 & 2 & 0 & 3 & 2 & 7 \\
\hline B1 & 2 & 0 & 12 & 8 & 22 \\
\hline B23 & 0 & 0 & 4 & 4 & 8 \\
\hline Total & 38 & 28 & 58 & 36 & 160 \\
\hline
\end{tabular}

Fig.1 Map of Fresco Lagoon showing sampling sites.

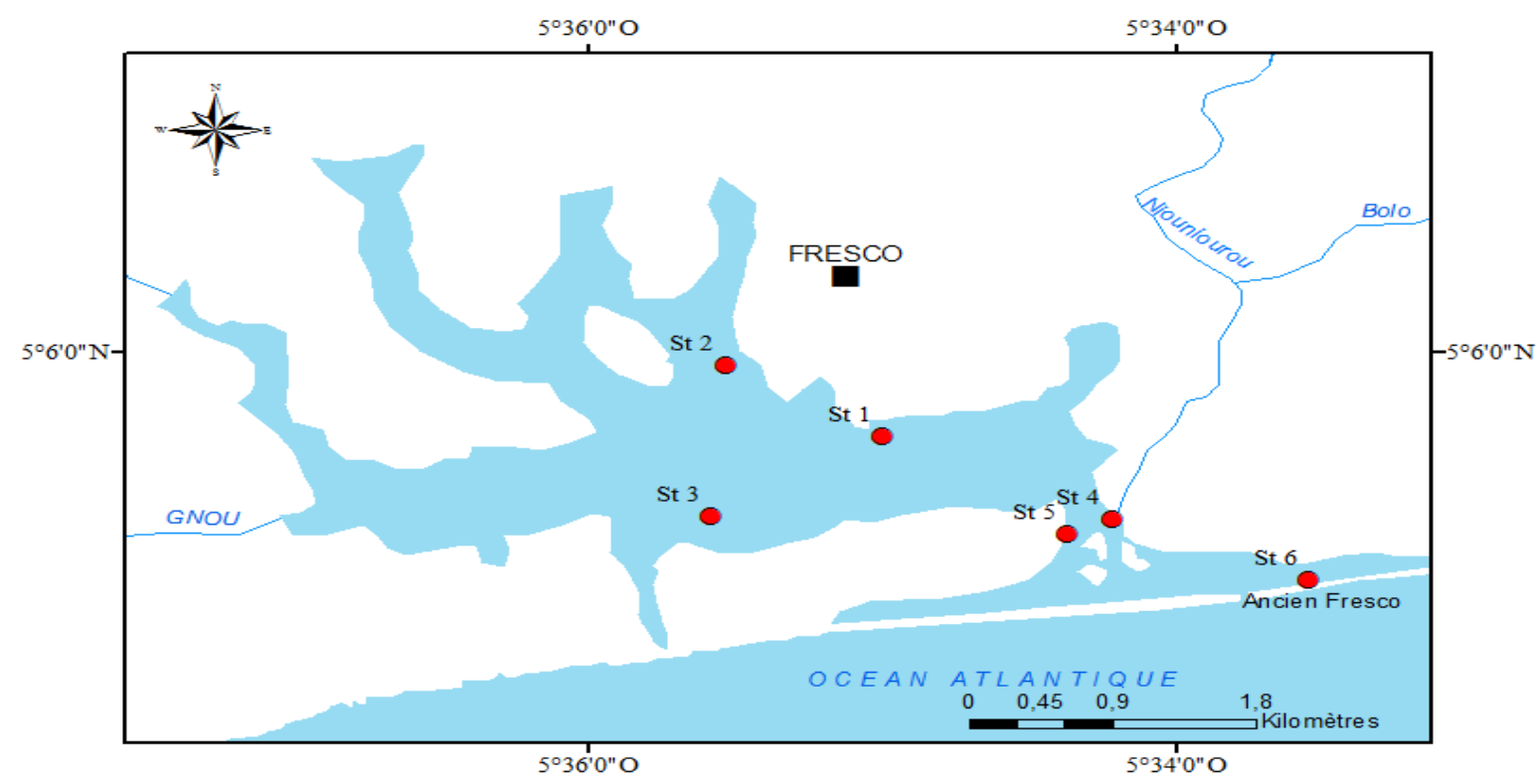

St : site 
Fig.2 Proportion of E. coli isolated according to the different parts of fish species analyzed

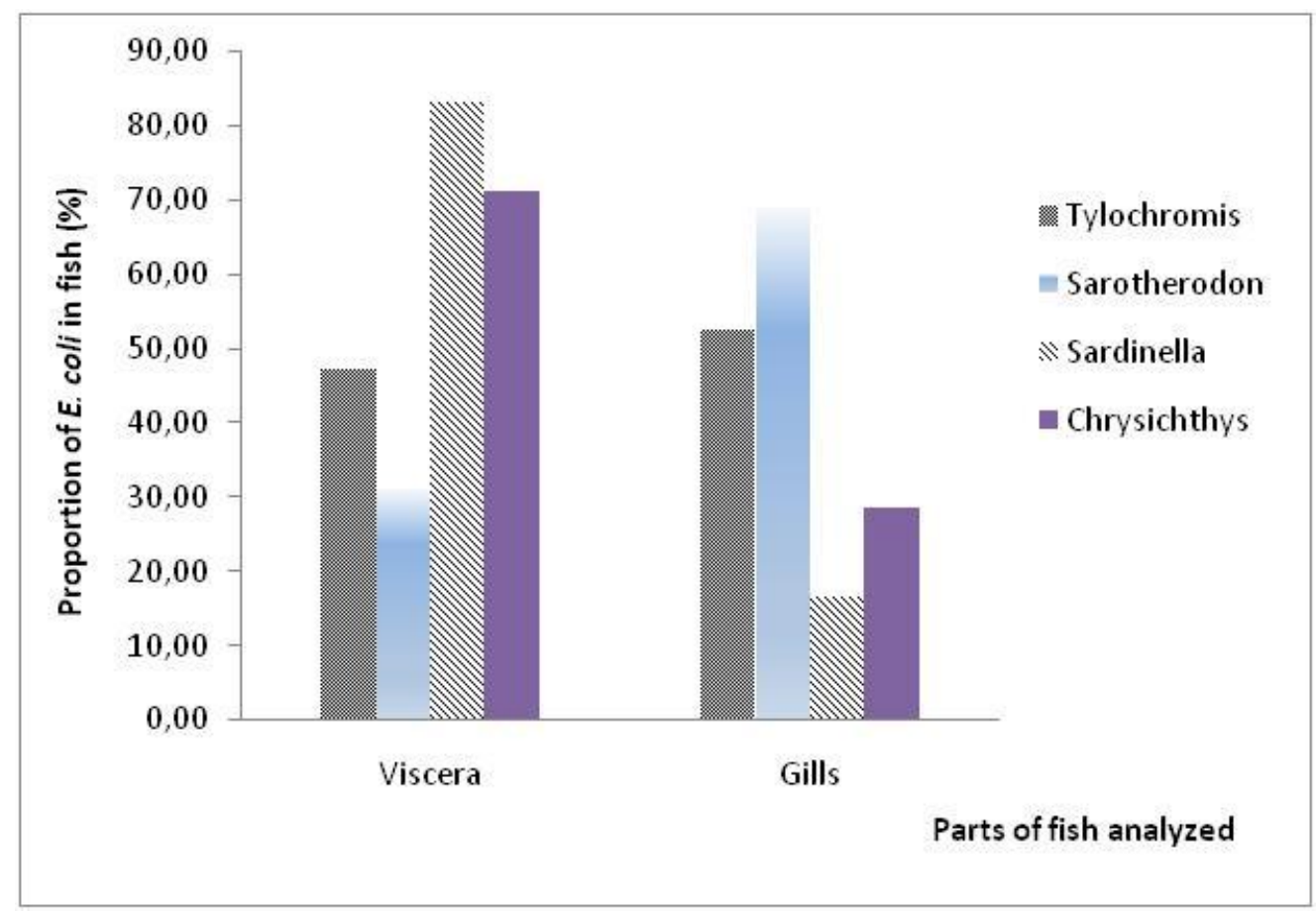

Fig.3 Proportion of E. coli phylogenetic groups according to parts of fish species (\%).

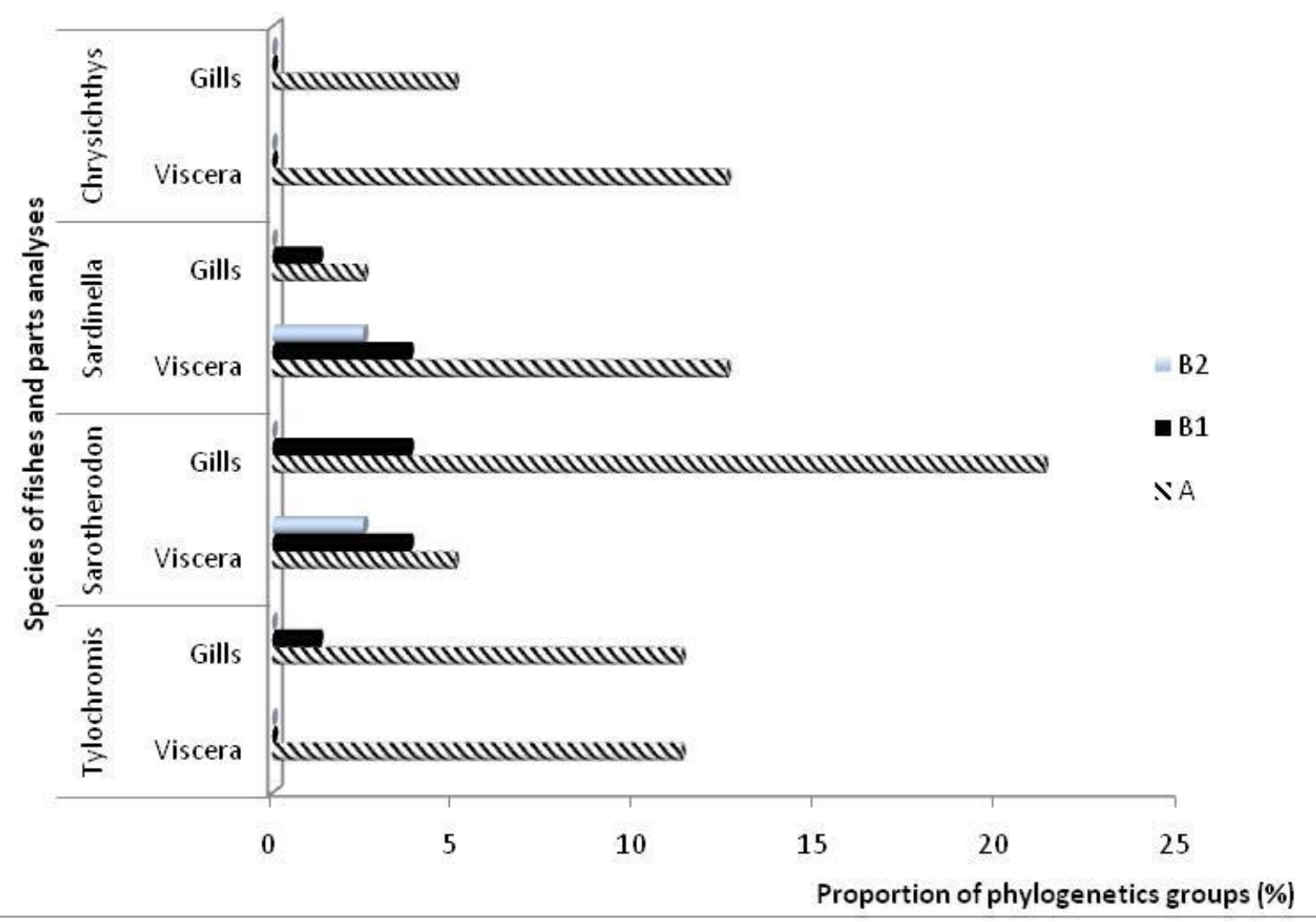


Fig.4 Correspondence analysis of sites using phylogenetic groups repartition.

ST1: site 1, ST2: site 2, ST3: site 3, ST4: site 4, ST5: site 5, ST6: site 6

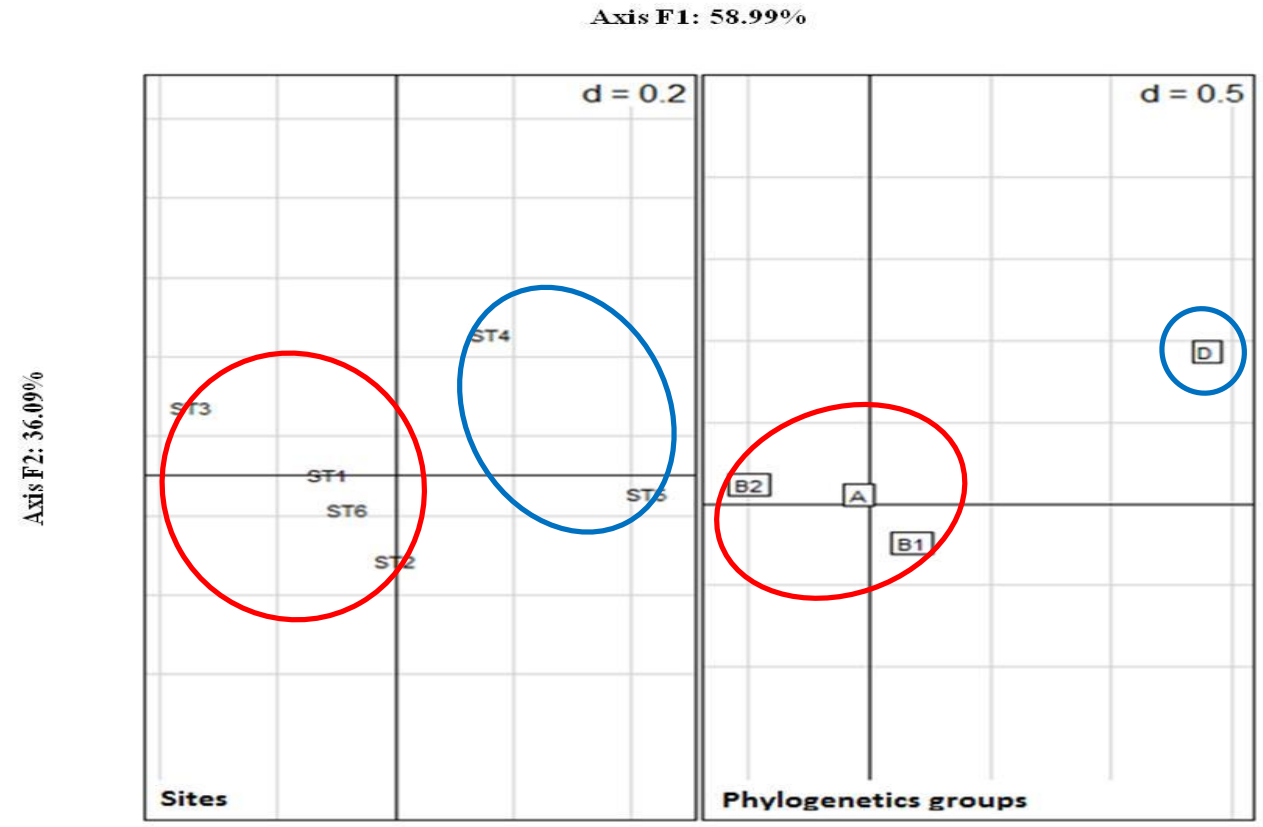

Fig.4 Dendrogram for clustering fishes according to $E$. coli phylogenetic subgroups repartition Chrys: Chrysichthys; Tylo: Tylochromis; Sard: Sardinella; Saro: Sarotherodon

A: Fish species contaminated by E. coli phylogenetic subgroup A1, B: Fish species contaminated by E. coli phylogenetic subgroup A1, C: Fish species contaminated by E. coli phylogenetic subgroup B1 and B2

Cluster Dendrogram

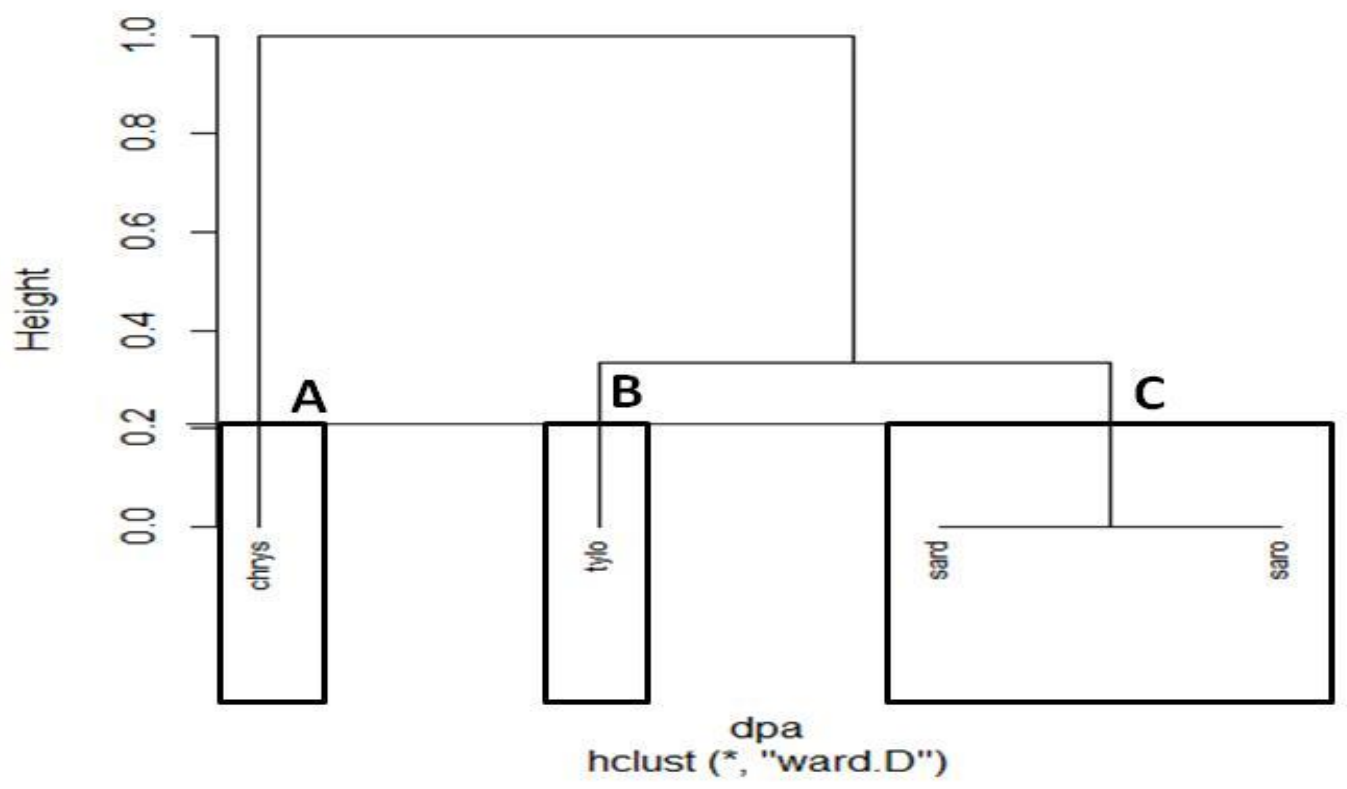


According to Hume (1999), host habitat, diet, "typical'" body temperature and gut morphology are all factors that influence the distribution of $E$. coli phylogenetic groups among host individuals.

Strains belonging to groups B2 and D are less represented in water and fish samples. These results are in agreement with those of Walk et al., (2007). Picard et al., (1987) found that B2 strains accounted for only $9 \%$ of examined commensal human strains. $E$. coli strains from group B2 are highly pathogenic and frequently responsible for extraintestinal infections (Lecointre et al., 1998; Duriez et al., 2001; Orsi et al., 2007) and for urinary tract infections in humans (Zhang et al., 2002). Extraintestinal pathogenic E. coli can be found in group D (Picard et al., 1999; Orsi et al., 2007) and according to Clermont et al., (2000), E. coli O157:H7could belong to this group. The smaller percentage of phylogenetic groups B2 and D found in our study confirms the hypothesis that these strains derive from commensal strains by the acquisition of chromosomal or extra-chromosomal virulence operons (Finlay and Falkow, 1997; Ochman et al., 2000). It is also reported that "black hole" genomic deletions that enhance pathogenicity or random functional point mutations that are adaptive for pathogenic environments (Sokurenko et al., 1998) may represent additional strategies of genome plasticity by which a commensal strain may become virulent. The presence of groups B2 and D in the water might suggest that Fresco lagoon can present a risk of extra-intestinal pathogenic $E$. coli for inhabitants who use this water for recreational activities. Strains of group B2 were also found in fishes. This finding raises serious worries in the sense that badly gutted and cleaned fish that have undergone little or no cooking can be a source of contamination.
In conclusion, the results obtained in this work indicate that the Fresco lagoon is not polluted according to the WHO guideline. Commensal and extra-intestinal pathogenic E. coli were isolated from water and fish samples. Fresco lagoon could represent a potential reservoir of extra-intestinal infections for the riverine populations and consumers. Therefore, riverine population must be educated in order to minimize the fecal contamination.

\section{References}

Clermont, O., S. Bonacorsi, and Bingen, E. 2000. Rapid and simple determination of the Escherichia coli phylogenetic group. Appl. Environ. Microbiol., 66: 4555-4558.

Costa, A. 2013. Escherichia coli in seafood: A brief overview. Adv. Biosci. Biotechnol., 4: 450-454.

Desmarais, T., H. Solo-Gabriele, and Palmer, C. 2002. Influence of soil on fecal indicator organisms in a tidally influenced subtropical environment. Appl. Environ. Microbiol., 68: 11651172.

Duriez, P., O. Clermont, S. Bonacorsi, E. Bingen, A. Chaventre, J. Elion, B. Picard, and Denamur, E. 2001. Commensal Escherichia coli isolates are phylogenetically distributed among geographically distinct human populations. Microbiol., 147: 1671-1676.

Finlay, B., and Falkow, S. 1997. Les thèmes communs dans la pathogénicité microbienne revisitée. Microbiol. Mol. Biol. Rev., 62: 136-169.

Hansen, D., J. Clark, S. Ishii, M. Sadowski, and Hicks, R. 2008. Sources and sinks of Escherichia coli in benthic and pelagic fish. J. Great lakes Res., 34: 228-234. 
Herzer, P., J. Inouye, S. Inouye, Whittam, T. 1990. Phylogenetic distribution of branched RNA-linked multicopy single-stranded DNA among natural isolates of Escherichia coli. $J$. Bacteriol., 172: 6175-6181.

Hume, I. 1999. Marsupial nutrition. Cambridge: Cambridge University Press.

Ishii, S., D. Hansen, R. Hicks and Sadowski, M. 2007: Beach sand and sediments are temporal sinks and sources of Escherichia coli in Lake Superior. Environ. Sci. Technol., 41: 22032209.

Johnson, J. and Stell, A. 2000. Extended virulence genotypes of Escherichia coli strains from patients with urosepsis in relation to phylogeny and host compromise. J. Infect. Dis., 181: 261-272.

Johnson, J., T. O'Bryan, M. Kuskowski, and Maslow, J. 2001. Ongoing horizontal and vertical transmission of virulence genes and papA alleles among Escherichia coli blood isolates from patients with diverse source bacteremia. Infect. Immun., 69: 5363-5374.

Joly, B. and Reynaud, A. 2003. Entérobactéries : systématique et méthodes de diagnostic. TEC and DOC 356 p. Ed. Lavoisier, Paris.

Kouadio, N., A. Dadié, A. Adingra, Y. Ake, and Dje K. 2011. Biotypes de Escherichia coli isolés des poissons et de l'eau de la lagune de Fresco, Côte d'Ivoire. J. Appl. Biosci., 38: 2523-2530.

Lecointre, G., L. Rachdi, P.Darlu, and Denamur, E. 1998. Escherichia coli molecular phylogeny using the incongruence length difference test. Mol. Biol. Evol., 15: 1685-1695.

Obiri-Danso, K. and Jones, K. 2000. Intertidal sediments as reservoirs for hippurate negative Campylobacters, Salmonellae, and faecal indicators in three EU recognised bathing waters in northwest England. Wat. Res., 34: 519-527.

Ochman, H.G., Lawrence, and Groisman, E. 2000. Lateral gene transfer and the nature of bacterial innovation. Nat., 405: 299-304.

Orsi, R., N. Stoppe, M., Sato, and Ottoboni, M. 2007. Identification of Escherichia coli from groups A. B1. $\mathrm{B} 2$ and $\mathrm{D}$ in drinking water in Brazil. J. wat. Health, 5: 323- 327.

Picard, B., J. Sevali-Garcia, S. Gouriou, P. Duriez, N. Brahimi, E. Bingen, J. Elion, and Denamur, E.1999. The link between phylogeny and virulence in Escherichia coli extraintestinal infection. Infect. Immun., 67: 546-553.

Picard, B., N. Picard-Pasquier, and Krishnamoorthy, $\quad$ R. 1987. Characterization of highly virulent Escherichia coli strains by ribosomal DNA restriction fragment length polymorphism. FEMS Microbiol. Lett., 82: 183-188.

Russo, T. and Johnson J. 2003. Medical and economic impact of extraintestinal infections due to Escherichia coli: focus on an increasingly important endemic problem. Microbes Infect., 5: 449-456.

Russo, T. and Johnson, J. 2000. A proposal for a new inclusive designation for extraintestinal pathogenic isolates of Escherichia coli: ExPEC. J. Infect. Dis., 181: 1753-1754.

Selander, R., D. Caugant, H. Ochman, J. Musser, M. Gilmour, and Whittam, T. 1986. Methods of multilocus enzyme electrophoresis forbacterial population genetics and systematics. Appl. Environ. Microbiol., 51: 873884. 
Soliman, M., R. Khalil, T. Saad and ElGamal, M. 2010. Isolation and identification of $E$. coli from cultured freshwater. J. Arabian. Aquac. Soc., 5: $19-34$.

Sujatha, K., P. Senthilkumaar, S. Sangeetha and Gopalakrishnan, M. 2011. Isolation of human pathogenic bacteria in two edible fishes. Priacanthushamrur and Megalaspiscordyla at Royapuram waters of Chennai. India. Indian $J$. Sci. Technol., 4: 539-541.

Unno, T., H. Dukki, J. Jeonghwan, L. SunNim, K. Gwangpyo, C. Ha Young, H. Joon, M. Sadowski, and Hor-Gil, H. 2009. Absence of Escherichia coli phylogenetic group B2 strains in humans and domesticated animals from Jeonnam province. Republic of Korea. Appl. Environ. Microbiol., 75: 5659-5666.
Walk, S., E. Alm, L. Calhoun, J. Mladonicky,and Whittam T. 2007. Genetic diversity and population structure of Escherichia coli isolated from freshwater beaches. Environ. Microbiol., 9: 2274-2288.

WHO. 1998. Draft guidelines for safe recreational water environment: coastal and freshwater; World Health Organization, Geneva.

Yagoub, S. 2009. Isolation of Enterobacteriaceae and Pseudomonas spp. from raw fish sold in fish market in Khartoum state. J. Bacterial. Res., 7: 085-088.

Zhang, L., B. Foxman, and Marrs, C. 2002. Both urinary and rectal Escherichia coli isolates are dominated by strains of phylogenetic group B2. J. Clin. Microbiol., 40: 3951-3955.

\section{How to cite this article:}

Nadège Kouadio-Ngbesso, Nazaire Kouassi, Kouadio Florent N'guessan, Ama Adingra, Bassa Antoine Yobouet, Adjéhi Dadié and Koffi Marcellin Dje. 2016. Relationship between the Phylogenetic Group of Escherichia coli Strains Isolated in Water and Fish in Fresco Lagoon (Côte d'Ivoire). Int.J.Curr.Microbiol.App.Sci. 5(10): 413-423. doi: http://dx.doi.org/10.20546/ijcmas.2016.510.047 